\title{
COVID-19, recovery policies and the resilience of EU ETS
}

\author{
Hanmin Dong ${ }^{1,2} \cdot$ Xiujie Tan ${ }^{3,4} \cdot$ Si Cheng ${ }^{5,6} \cdot$ Yishuang Liu' ${ }^{7}$ \\ Received: 2 September 2021 / Accepted: 18 November 2021 \\ (c) The Author(s), under exclusive licence to Springer Science+Business Media, LLC, part of Springer Nature \\ 2021
}

\begin{abstract}
COVID-19 pandemic and its recovery bring opportunities and threats for global climate governance and further challenge climate related assets. In this study, we analyze the efficiency of government response policies and fiscal policies on green recovery by observing the variation characteristics of carbon allowance prices in the EU emission trading system (EU ETS). Using the OLS and threshold methods in the original time scales, we find that: (1) The EUA prices had an inverted U-shaped relationship with the number of new confirmed cases and deaths. (2) Government response policies had a better effect than fiscal policies when mitigating the negative impact of the pandemic. After decomposing and reconstructing the time series, the multiscale analysis indicates that: (3) The carbon price fluctuated in the short term with the increasing number of newly confirmed cases (or deaths) but gradually recovered due to the recovery policies. (4) Government response policies had a "stop-loss" effect in the short term, and then working alongside fiscal policies, sustained and promoted the development of the EU ETS and green recovery. In the post-COVID-19 era, we suggest the combination of various policies to convert the current health crisis into opportunities for climate change mitigation.
\end{abstract}

Keywords EU ETS · COVID-19 pandemic · Government responses · Fiscal policies · Green recovery

JEL Classification G0 $\cdot \mathrm{H} 30 \cdot \mathrm{Q} 58$

\section{Introduction}

Global public health emergencies have short- and long-term socio-economic impacts. The outbreak of the coronavirus disease (hereinafter referred to as COVID-19 pandemic) starting in late 2019 has caused not only immense human suffering and loss

Yishuang Liu

vanavampire@whu.edu.cn

Extended author information available on the last page of the article

Published online: 07 January 2022 
of life (Devpura and Narayan 2020), but also unprecedented uncertainty and consequent economic imbalances, inflation, and a slowdown in consumption (Baldwin and Di Mauro 2020; Shaikh 2021; Tahir and Batool 2020; Vasileiou et al. 2021, to name but a few). Apart from the direct consequences of the health and economic crises, the pandemic has also generated a deeper indirect crisis, such as the disruption to social governance, political relations, and international orders generated from popular fears.

As a result of the COVID-19 pandemic and economic shutdown, global energy demand and carbon emissions were expected to fall by $6 \%$ and $8 \%$, respectively, by the end of April 2020 (IEA 2020). As the emission trading system (ETS), the critical tool to mitigate carbon emissions and combat climate change in the EU, regulates half of the EU's carbon emissions, its demand and prices should have plummeted during the COVID-19 pandemic (Mintz-Woo et al. 2020; Sartzetakis 2021). However, the prices of EU carbon allowances (EUAs) have fallen less in 2020 than that in the 2008 financial crisis. ${ }^{1}$ The difference in the EUA price dynamics between the two crises (the 2008 financial crisis and the 2019 COVID-19 pandemic) is partly attributed to legislative changes in the EU ETS. ${ }^{2}$ Apart from the mechanism promotions more noteworthy are the government responses and fiscal policies.

To slow down pandemic transmission and economic shutdown, governments worldwide have taken unprecedented emergency measures, including various antipandemic measures and economic stimulus packages (Bargain and Aminjonov 2020; Phan and Narayan 2020; Vasileiou et al. 2021). The anti-pandemic measures include isolation measures, stringent testing policies, and large-scale contact tracing (Ashraf 2020b), while stimulus packages are provided by governments, from finance ministries to central banks, to revive the economy and manufacturing in particular (Ashraf 2021; Chang et al. 2021; Haldar and Sethi 2020; Shi et al. 2021). To mitigate the adverse impact of the pandemic and rebuild a post-COVID-19 Europe, the EU injected an approximately $€ 750$ billion fiscal stimulus plan. This plan could be considered as an extension and acceleration of the European Green Deal, as one of its priorities is to support the green transition.

To turn pandemic-related emission decline and EU ETS recovery, effective policies are necessary (Shan et al. 2021). In the post-COVID-19 era, we attempt to evaluate the efficiency of government responses and fiscal policies on green recovery by observing the variation characteristics of EUAs prices. Hence, this study first examines the impact of pandemic spreads on EU ETS from January 24 to July 23, 2020. Second, we

\footnotetext{
1 Based on the experience of the 2008 financial crisis, when the wave of recession affected the EU ETS, the price of the EUA fell to very low levels as the supply-demand imbalance increased (Elkerbout and Zetterberg 2020). However, in the post-financial-crisis era, even though the economic activities started to recover, the EUA price remained below $€ 10 /$ ton for approximately the next 9 years. Faced with the current COVID-19 outbreak, the EUA price fell from €24/ton at the beginning of 2020 to $€ 16 /$ ton on March 20 with a total decrease of more than $30 \%$. Compare with the fluctuations in the 2008 financial crisis, the decline in the EUA price was smaller, and the subsequent price recovery was relatively fast (Gerlagh et al. 2020). For example, the EUA price rose to $€ 22 /$ ton by June 2020 (Azarova and Mier 2020), indicating that it was well regulated and protected during the COVID-19 pandemic.

2 These measures included the introduction of the Market Stability Reserve mechanism and improved Linear Reduction Factor (Azarova and Mier 2020; Bocklet 2020; Elkerbout and Zetterberg 2020; Gerlagh et al. 2020).
} 
add two recovery policies (government responses and fiscal policies) into regression, where a threshold model is applied to determine when governments adopted stricter prevention policies, and the EU Recovery Plan is considered as the start of fiscal policies. Third, we employ the noise-assisted multivariable empirical mode decomposition (NA-MEMD) method to decompose and reconstruct the time series into high-frequency and low-frequency terms, therefore, we can discuss the effects of government responses and fiscal policies on EU ETS from different time scales.

The contribution of this study is twofold. First, we creatively explore the impact of COVID-19 pandemic and recovery policies on the EU ETS. The existing literature has analyzed the possible factors affecting carbon prices; however, few studies considered the shocks stemming from sudden public health risks. Therefore, our study enriches the drivers of carbon prices, providing empirical evidence for the carbon market to enhance its risk resilience. Second, previous studies have investigated the financial and energy market responses to COVID-19 pandemic and related government policies (Ashraf 2020a, 2021; David et al. 2021; Shaikh 2021; Sun et al. 2021; Takahashi and Yamada 2021; Vasileiou et al. 2021); but few of them focused on riskier carbon markets (Chai and Zhou 2018; Zeng et al. 2021; Zhu et al. 2020). This study combines climate challenges with health risks from multiple time scales and provides new ideas for turning the COVID-19 crisis into possible climate opportunities.

The rest of the study is structured as follows. We review relevant literature in Sect. 2. The data and methods applicable to this study are described in Sects. 3 and 4, respectively. Then, our baseline empirical results are presented in Sect. 5. Section 6 provides a further analysis in which the threshold model and the NA-MEMD method are employed. Finally, in Sect. 7, the study is summarized and discussed.

\section{Literature review}

The epidemic is a major contributor to death, disability, and injury, and thus, governments are expected to work together to prevent it. As shown in history, 20-40 million people worldwide were killed by the influenza pandemic in 1918 (Mills et al. 2004). The economic gains of many countries, such as Guinea, Liberia, and Sierra Leone, have been evaporated due to the Ebola epidemic (Cheng 1995; Norouzi, et al. 2020). Recent studies also examine the impacts of the ongoing COVID-19 pandemic on the social, economic, and financial markets (Chang et al. 2020; Iyke 2020). For example, the securities market worldwide reacted to COVID-19 with unprecedented volatility and a sharp tumble (Al-Awadhi et al. 2020; Ashraf 2021; Baker et al. 2020; Goodell 2020; Mishra et al. 2020; to name but a few). Apart from the financial market, the COVID-19 pandemic impact on commodity (especially energy) markets has also been investigated: higher uncertainty has led to the collapse in supply and demand and the increase in price elasticity (Devpura and Narayan 2020; Gil-Alana and Monge 2020).

Some studies also show the interest in the role of public policy in epidemics prevention. Strict physical measures, like public lockdowns and travel restrictions, always have a very significant effects on controlling the epidemic. Lockdowns, for 
example, are effective in reducing pandemic transmission risks (Brauner et al. 2021; Flaxman et al. 2020; Haug et al. 2020). However, the increase in economic distance imposes a threat to employment and production and thus leads to one of the most severe economic recessions since 1990 (Anderson et al. 2020; Barrot et al. 2020; Hellewell et al. 2020). As the supplement of government response, central banks and supervisory departments also react to the COVID-19 pandemic by relaxing financial conditions and increasing benefits subsides (Alberola et al. 2021). It has been estimated that policy supports prevent worse economic outcomes in the U.S and fiscal supports facilitate the recovery in Canada (Chudik et al. 2021).

Before the COVID-19 outbreak, climate and energy policies have been emphasized by the global and national governments, institutions, and scholars (Steffen et al. 2020). To combat climate change and achieve carbon neutrality, a series of policies and frameworks have been introduced worldwide, including the ETS and Green Deal in the EU. However, with the spread of COVID-19 pandemic, dramatic changes have happened in economic and political circumstances. With the drastic change in the economy and policies, climate change problems and related solutions have experienced opportunities and challenges. The outbreak offers new solutions and development opportunities to the climate change mitigation (Zhang et al. 2021). In terms of short-term behaviors, government policies have restricted production, transportation, and trade in most economic sectors, leading to a depression in demand and supply (Hauser et al. 2020; Klemeš et al. 2020). This suggests less consumption in the energy supply sector (Malliet et al. 2020; Ran et al. 2021; Yaya et al. 2020), and fewer emissions of GHG and pollutants in the production sector (Balsalobre-Lorente et al. 2020; Chakraborty et al. 2020). ${ }^{3}$ All of these could alleviate climate change and global warming to some extent. For the long-term development, the structure optimization of energy and industry during the COVID19 pandemic would be conducive to combat climate change. In one aspect, public policies (such as factory closures) have caused an excess stock of bulk commodities (such as steel and cement) and thus encouraged the transformation and upgrading of manufacturing industries (especially in highly polluting industries). For another, travel restrictions and city lockdowns have transformed the way people work and live (Gu et al. 2020). For example, teleworking and online education have enabled the Internet industry to experience explosive growth, laying a solid foundation for the future development of the service industry (Zhu and Zhang 2020).

On the other hand, the COVID-19 pandemic has posed challenges to climate governance as well. According to Forster et al. (2020), the effect of various antipandemic measures would be negligible to alleviate long-term global warming, and global temperatures are likely to fall by only $0.005-0.01{ }^{\circ} \mathrm{C}$ by 2030 . This means that despite the huge sacrifices made by human beings during the COVID-19 pandemic, it is still difficult to reach the $1.5{ }^{\circ} \mathrm{C}$ temperature reduction target based on Paris Climate Agreement (Elliott et al. 2020). In addition, due to the COVID-19

\footnotetext{
${ }^{3}$ Retrieved from International Energy Agency. The impacts of the COVID-19 crisis on global energy demand and $\mathrm{CO}_{2}$ emissions. https://www.iea.org/reports/global-energy-review-2020. Last accessed October 20, 2021.
} 
and its resulting recession, future investment in renewable energy would fall $10 \%$ (Zhang 2021). In the post-COVID-19 era, with the restrictions, such as factory closures, travel restrictions, and city lockdowns are eventually lifted, a recovery in production and life will probably lead to a rapid rebound in carbon emissions. That is to say, carbon emissions might only decrease in the short term, but catch up again in the long term (Gillingham et al. 2020; Le Quéré et al. 2020; Ou et al. 2020). After the COVID-19 pandemic, if governments relax their environmental and climate regulations to stimulate economic recovery (Zhang 2021), the total amount of carbon emissions might not significantly decline but shift across time (Bocklet 2020). Even worse, carbon emissions might exceed pre-COVID-19 levels due to the retaliatory production and consumption in the aftermath of the pandemic (Gardiner 2020).

As a policy instrument of the market mechanism, the price of carbon trading allowance is a key to controlling carbon emissions and evaluating the market function (Benz and Trück 2009; Chevallier 2011), while the association between COVID-19 pandemic and EU ETS is rarely studied in academic research. The impact of the COVID-19 pandemic and recovery policies on climate change issues is undoubtedly accompanied by value changes of climate-related assets (Sartzetakis 2021). Based on previous analysis of the impact of COVID-19 and recovery policies on climate change and carbon emissions, the European Union emissions trading system (EU ETS) might be affected by three direct major shocks: (1) a temporary reduction in the demand for the EU emission allowances (EUA) caused by the COVID-19 pandemic ${ }^{4}$; (2) the uncertainty in the demand for emission allowances caused by the overlapping of economic stimulus packages under EU economic recovery policies; and (3) permanent reduction in the supply of emission allowances due to the strengthening of Green Deal standards (Bruninx and Ovaere 2021).

Pandemic and policies uncertainty affects macroeconomic and financial variables (Yu et al. 2021). In addition to the abovementioned direct effects, the COVID-19 pandemic may potentially indirectly influence carbon price changes through some driving factors, including market fundamentals, production activity, and so on. ${ }^{5}$

\section{Data and materials}

\subsection{Independent variable: COVID-19 $\left(\right.$ case $\left._{t}\right)$}

On December 31, 2019, China reported cases of unexplained pneumonia in Wuhan, Hubei to the World Health Organization who on January 30, 2020, declared it as

\footnotetext{
${ }^{4}$ During the COVID-19 pandemic, carbon emissions in EU ETS were $38 \mathrm{Mt} \mathrm{CO}_{2} /$ month lower than usual (Bruninx and Ovaere 2020).

${ }^{5}$ Examples include economic shocks, policy regulation, market fundamentals, climatic conditions, production activity, energy prices, and stock markets (Alberola et al. 2008; Boersen and Scholtens 2014; Christiansen et al. 2005; Creti et al. 2012; Deeney et al. 2016; Dutta et al. 2018; Keppler and MansanetBataller 2010; Mansanet-Bataller et al. 2007; Ye and Xue 2021; Zhu et al. 2019).
} 


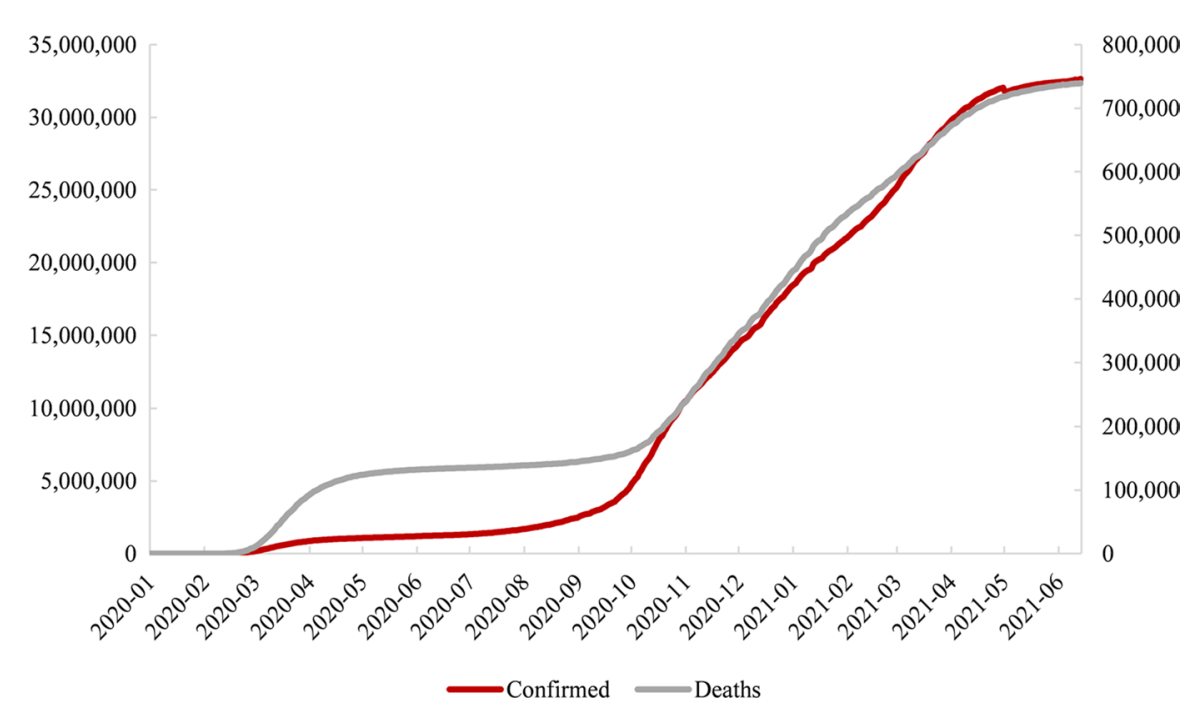

Fig. 1 Number of newly confirmed (left axis) and death cases (right axis)

the outbreak of the "new coronavirus pneumonia" and a public health emergency of international concern. We collect and aggregate the data related to the outbreak in 27 EU member states from the China Stock Market \& Accounting Research Database (CSMAR). ${ }^{6}$ Figure 1 plots the time series of cumulated confirmed cases and deaths from January 2020 to June 2021.

The outbreak of COVID-19 disease first appeared in Italy on January 24, 2020, and then gradually spread to other EU countries. As Fig. 1 shows, the number of confirmed cases and deaths increased from gradually at the beginning of March to dramatically in early October 2020. In the mid-2021, the COVID-19 pandemic is still affecting the EU countries, and the governments are still employing various anti-pandemic methods to slow down or stop its spread. As of June 30, 2021, the EU member states had reported 32,504,638 cumulative confirmed cases, including 737,985 deaths. We apply confirm $_{t}$ and death $_{t}$ to denote the total number of newly confirmed cases and deaths in the EU member states on the day $t$, respectively.

\footnotetext{
${ }^{6}$ CSMAR is one of the databases of Shenzhen Guotaian Education Technology Co., Ltd, which is one of the few economic databases in China with large-scale and accurate information. CSMAR contains eight series of data including stocks, funds, bonds, financial derivatives, listed companies, the economy, industries, high-frequency data, and customized data. Retrieved from https://www.gtarsc.com/. Last accessed October 20, 2021.
} 


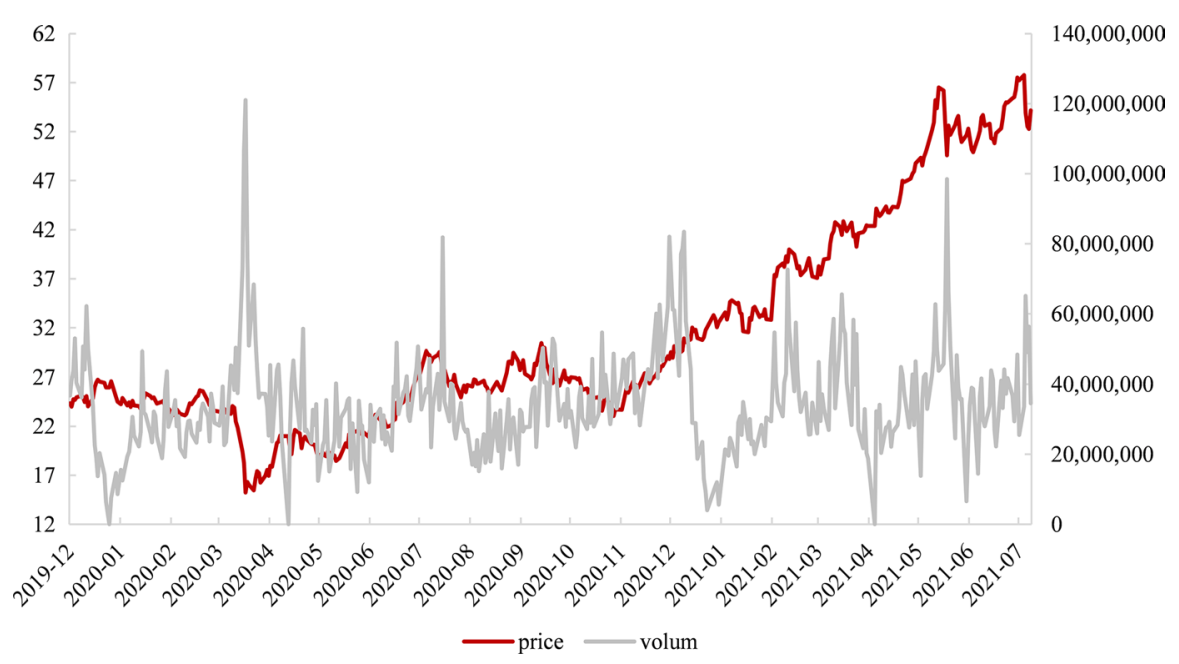

Fig. 2 EUA futures settlement price (left axis) and trading volume (right axis)

\subsection{Dependent variable: carbon price $\left(e u a_{t}\right)$}

The EU carbon price data are collected from the China WIND database. ${ }^{7}$ Figure 2 plots the line graph of the EUA futures settlement price $\left(e u a_{t}\right)$ and trading volume since December 2019, showing that the EU carbon price was not affected by the COVID-19 pandemic until February 2020, floating between $€ 20$ and $€ 25$. At that point, the COVID-19 pandemic had just originated in China and not spread to the EU countries. The price began to fall significantly in the wake of the global pandemic during March 2020. The EU carbon price decreased sharply, falling by more than $27 \%$ to $€ 16.03 /$ ton between March 16 and 20, 2020. Just on March 18, the price fell further by $17 \%$, hitting a record low since November 2018.

Since May 2020, the EU member states have been relaxing COVID-19 restrictions to promote economic recovery. Consequently, the EU GHG emissions that had temporarily been reduced after the COVID-19 outbreak began to rise again. Carbon emissions increased with the revival of the global economy and production. Similarly, the EU carbon price gradually recovered, returning to its pre-pandemic level between June 2020 and July 2020 (Gerlagh et al. 2020). Considering that the complex price changes resulted from more than pandemic restrictions and control policies after August 2020, the sample period of this study was observed from January 24 to July 23, 2020.

\footnotetext{
7 WIND is a financial data and analytic tools provider in China, covering domestic and foreign stocks, funds, bonds, foreign exchange, insurance, futures, financial derivatives, spot trading, macroeconomics, financial news, and other fields. WIND is frequently cited by the Chinese and English media, research reports, and academic papers. Retrieved from https://www.wind.com.cn/Default.html. Last accessed October 20, 2021.
} 


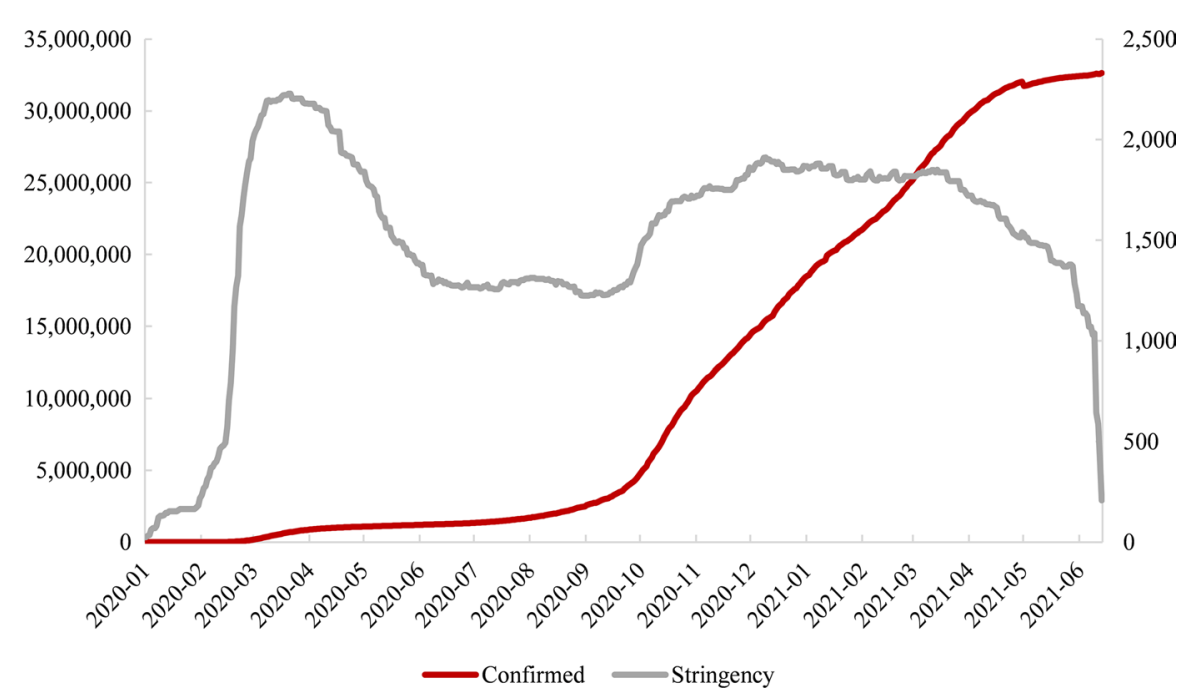

Fig. 3 Number of new confirmed cases (left axis) and the Stringency Index (right axis)

\subsection{Policy variables: government responses $\left(\right.$ govern $_{t}$ ) and fiscal policies ( fiscal $_{t}$ )}

As the socio-economic impact of the COVID-19 outbreak was exacerbated by the prolonged lockdowns, countries worldwide announced various economic stimulus packages (Obergassel et al. 2020). We divide the main EU recovery policies into two categories and add two dummy variables govern $_{t}$ and fiscal $_{t}$ into regressions.

First, we obtain the government responses $\left(\right.$ govern $_{t}$ ) using Government Response Stringency index (stringency $y_{t}$ ) and the threshold model that would be introduced in Sect. 4.2. The Stringency index is obtained from The Oxford COVID-19 Government Response Tracker Database (OxCGRT), describing the changes in closure policies across countries along three dimensions: interventions for close contacts and public gatherings, government financial measures, and health system policies ${ }^{8}$ (Hale et al. 2020). Figure 3 shows the time series of the daily number of accumulated confirmed cases and the average Government Response Stringency Index for the EU member states.

\footnotetext{
${ }^{8}$ The Oxford COVID-19 Government Response Tracker Database (OxCGRT) extensively quantifies government responses to COVID-19 from 3 dimensions and 13 indictors based on news reports, government announcements, and public information. To be specific, Stringency Indicator records information on social distancing policies and is coded from 8 indicators including the closure of school or workplace, cancellation of public events, restrictions on gathering, stay-at-home requirement, restrictions on internal movements; Containment and Health Indicator is coded from3 indicators representing public information campaigns, testing policy, and extent of contact tracing. Economic Support Indicator is constructed from 2 indicators including government income support and household debt/ contract relief. This database is widely used by academic research and its providers-Hale et al (2020)'s paper has been cited more than 800 times by October 2021. Retrieved from https://data.humdata.org/dataset/oxford-covid-19-gover nment-response-tracker. Last accessed October 20, 2021.
} 
Table 1 Descriptive statistics of variables

\begin{tabular}{lllllr}
\hline Variable & Obs & Mean & SD & Min & \multicolumn{1}{c}{ Max } \\
\hline Eua & 128 & 3.146 & 0.145 & 2.787 & 3.422 \\
Confirm & 128 & 7.256 & 3.123 & 0 & 10.403 \\
Death & 128 & 4.882 & 2.621 & 0 & 8.253 \\
Stringency & 128 & 6.862 & 1.048 & 3.259 & 7.706 \\
Stock & 128 & 5.881 & 0.106 & 5.637 & 6.075 \\
Coal & 128 & 3.846 & 0.084 & 3.675 & 3.955 \\
Oil & 128 & 3.660 & 0.286 & 3.012 & 4.122 \\
Gas & 128 & 2.844 & 0.273 & 2.234 & 3.372 \\
Surprise & 128 & 4.957 & 1.208 & 0 & 5.918 \\
\hline
\end{tabular}

This table reports the descriptive statistics of each variable from January 24,2020 , to July 23, 2020. All variables are in natural logarithmic form

Further, we consider the EU recovery plan as a proxy variable for the fiscal policies $\left(\right.$ fiscal $_{t}$ ). This $€ 750$ billion fiscal plan was proposed by the European Commission, including a range of transformative measures to lead green recovery and emphasizes that all budget expenditures must be consistent with the GHG reduction as per the Paris Climate Agreement and 2050 "carbon neutrality" targets. Thus, we regarded the adoption date of the EU recovery plan (May 27, 2020), as the commencement of the special fiscal policies, fiscal $_{t}$ is set to 1 for the period thereafter, and 0 otherwise.

\subsection{Control variables}

The carbon price is affected not only by the pandemic, but also from various factors including market forces, institutional arrangement, and energy prices (Aatola et al. 2013; Alberola et al. 2008; Benz and Trück 2009; Chevallier 2009; Creti et al. 2012; Gerlagh et al. 2020; Hintermann 2010). Therefore, the control variables in this study mainly comprise economic factors and energy prices to reflect changes on the demand side of carbon allowances. ${ }^{9}$ Specifically, they include stock price (European Index of $s t o c k_{t}$ ), coal price (IPE Rotterdam coal futures settlement price, coal $_{t}$ ), crude oil price (Brent crude oil futures settlement price, oil t), natural gas price (IPE UK gas futures settlement price, gas $_{t}$ ), and general economic conditions (Citi Economic Surprise Index for the Eurozone, surprise $_{t}$ ). Since the variables have different dimensions, we treated all the continuous variables logarithmically to enhance data smoothness and reduce heteroscedasticity. Data are obtained from the CSMAR and WIND databases. All the continuous variables are in natural logarithmic form, and Table 1 shows the descriptive statistics.

\footnotetext{
${ }^{9}$ Here, we do not consider the supply of EUA, as it depends entirely on the cap on emissions set by the European Commission and quantities allocated to individual firms (Batten et al. 2021).
} 


\section{Method and model}

\subsection{Baseline model}

As an emerging market, the carbon market is influenced not only by energy prices and carbon emissions, but also by external factors such as economic shocks, political events, the natural environment, and technological advancements (Zhu et al. 2019). Specifically, during the COVID-19 pandemic, we must consider the impact of medical events and recovery policies on the EU carbon price. First, we use the ordinary least squares (OLS) model to estimate the overall impact of the COVID-19 crisis on the EU ETS carbon price. The model is set up as follows:

$$
\mathrm{eua}_{t}=\alpha+\beta_{1} \text { case }_{t}+\beta_{2} \text { case }_{t}^{2}+\beta \text { controls }_{t}
$$

where subscript $t$ represents the time when the variables take values. The dependent variable eua $a_{t}$ denotes the futures settlement price of the EUA. The independent variable case $_{t}$ denotes the number of new cases including confirmed cases ( confirm $\left._{t}\right)$

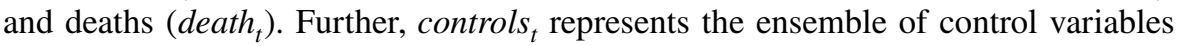
(as described in Sect. 3.4).

\subsection{Threshold model}

Government response is influenced by epidemic spread and prevention (Elgin et al. (2020). Typically, government policy becomes more stringent only after a certain number of deaths and loss of property. Thus, we employ a threshold approach (Hansen 1999) to investigate the non-linear relationship between the government responses and pandemic cases and identify the point at which government policies became more stringent. The model is formulated as follows:

$$
\text { stringency }_{t}=\alpha+\gamma_{1} \text { case }_{i} F\left(q_{\mathrm{it}} \leq \lambda\right)+\gamma_{2} \text { case }_{\mathrm{it}} F\left(q_{\mathrm{it}} \geq \lambda\right)+\varepsilon_{\mathrm{it}}
$$

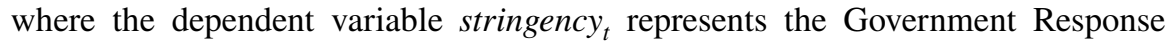
Stringency index obtained from OxCGRT. We selected the number of cases, case $_{i}$, as the threshold variable with the same setting as in Eq. (1). $F$ represents an exponential function, and $\lambda$ and $q$ represent the threshold value and threshold variable, respectively. $\alpha$ is the constant term of the equation. In particular, $\lambda$ implies that the government would take more proactive measures to deal with the pandemic once $\lambda$ cases are reported.

Calculated from threshold regression as Eq. (2), govern ${ }_{t}$ is set to $1^{10}$ when the number of cases $\left(\right.$ case $_{t}$ ) is greater than the threshold value $\lambda$, indicating that the government adopts a more stringent economic package in response to the COVID-19

\footnotetext{
${ }^{10}$ If the Government Response Stringency Index is added to Eq. (1) directly, multicollinearity among the number of confirmed cases and deaths may occur. Therefore, this study uses a threshold model to determine the point at which the government measures against the pandemic became more stringent (or measures against the pandemic became more effective).
} 
outbreak; otherwise, it equals to 0 . Then, we add a dummy variable ( policy $_{t}$ ) to the baseline model Eq. (1) to evaluate the policy intervention of government responses $\left(\right.$ govern $\left._{t}\right)$ and fiscal policies $\left(\right.$ fiscal $\left._{t}\right)$. Therefore, the policy-augmented baseline model is formulated as follows:

$$
\text { eua }_{t}=\alpha+\beta_{1} \text { case }_{t}+\beta_{3} \text { case }_{t}^{2}+\beta_{3} \text { policy }_{t}+\beta \text { controls }_{t}
$$

\subsection{NA-MEMD method}

The existing literature has comprehensively examined the linear relationship between financial assets and their drivers but ignores the complex non-linear relationship among different markets (Xu et al. 2019). In addition, a static analysis could only capture the drivers of carbon prices in a single timescale but fails to examine the short- and long-term driving mechanisms from different time scales (Kim and Koo 2010). To overcome such weaknesses, a multiscale analysis is necessary to identify the driving mechanisms of carbon prices during the COVID-19 pandemic.

Empirical mode decomposition (EMD) method is an effective method to deal with instability and nonlinearity, with the ability to adaptively transform original data into a set of intrinsic mode function (IMF) from high to low frequency based on its local features. Each IMF should satisfy two conditions: (1) the number of extreme points and the number of zero-crossing points in IMF are same or with at most 1 difference; (2) the mean of upper and lower enveloped defined by the local extreme value is equal to zero at any point (Huang et al. 1998). ${ }^{11}$ However, the mode mixing problem occurs after EDM and it ignores the intrinsic correlation among each series by considering each vector as an independent process (Yu et al. 2015).

Therefore, Rehman and Mandic (2010) developed the multivariate extension of empirical mode decomposition (MEMD) method, which overcomes the shortcoming of EMD and addresses the temporal and spatial characteristics in the relation to multichannel signals. In this study, the noise-assisted MEMD (NA-MEMD) method is introduced for preprocessing multichannel series. ${ }^{12}$ As for the input signal $x(t)=\left\{x_{1}(t), x_{2}(t), \ldots, x_{v}(t)\right\}$, the outline of NA-MEMD algorithm is presented as follows (Ur Rehman and Mandic 2011):

(a) Generate s-channel $(\mathrm{s} \geq 1)$ uncorrelated White Gaussian Noises (WGNs) $n(t)=\left\{n_{1}(t), n_{2}(t), \ldots, n_{s}(t)\right\}$, whose length is $L$, the same as that of the original signal $x(t)$;

(b) Add s-channel $n(t)$ into v-channel original signal $x(t)$ and obtain $q=s+v$ channel multivariate signals $z(t)=\left\{z_{1}(t), z_{2}(t), \ldots, n_{q}(t)\right\}$;

\footnotetext{
${ }_{11}^{11}$ Empirical Mode Decomposition (EMD): $x(t)=\sum_{i-1}^{n} I M F_{I}(t)+r_{n}$.

12 The NA-MEMD method applies the noise-assisted analysis method into MEMD, a dyadic filter bank on each channel while adding certain multi-dimensional White Gaussian Noises (WGNs) together with the original signals which are decomposed by using MEMD. For mode-alignment and mode mixing, the NA-MEMD is optimal compared with MEMD and EEMD (Zhang et al. 2017a; Zhang et al. 2017b).
} 


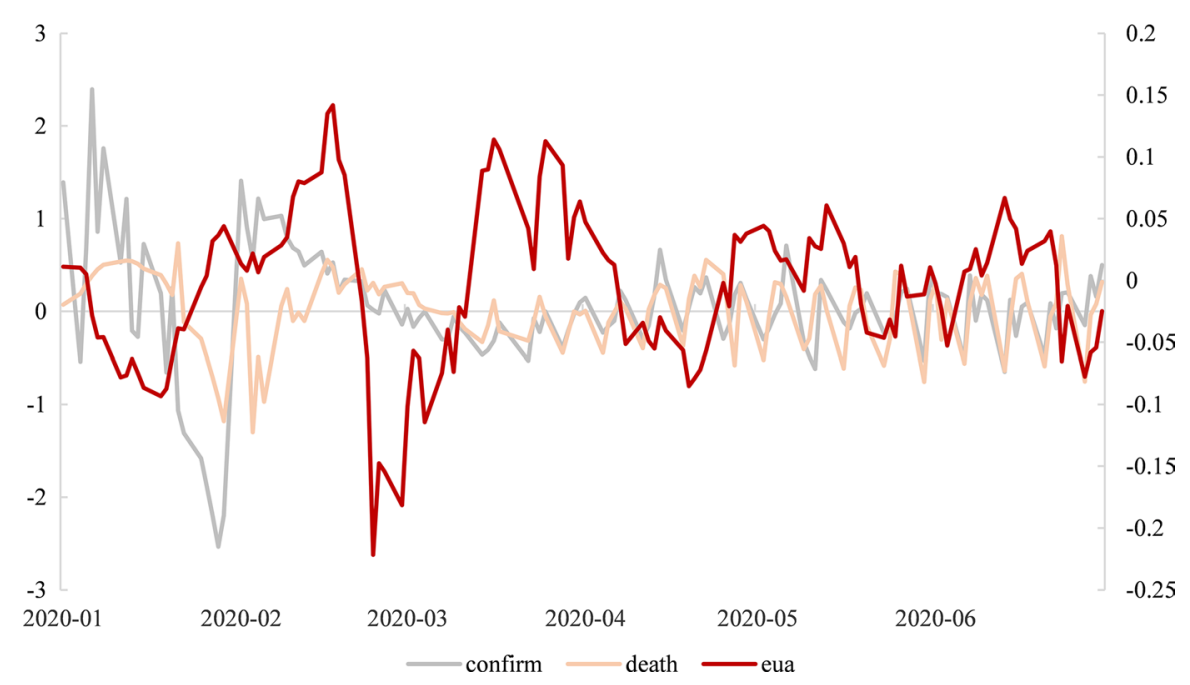

Fig. 4 High-frequency results

(c) Choose an appropriate point set for sampling a $(q-1)$ sphere and obtain a q-dimension direction vector $d^{\theta_{i}}$;

(d) Calculate the project of $z(t)$ along the direction vector $d^{\theta_{i}}$, giving $\left\{p^{\theta_{i}}(t)\right\}_{t=1}^{T}$ as the set of projection;

(e) Extract the time instant $t_{j}^{\theta_{i}}$ corresponding to the local maxima of the set of the projected signals $\left\{p^{\theta_{i}}(t)\right\}_{t=1}^{T}$;

(f) By interpolating the set $\left[t_{j}^{\theta_{i}}, z\left(t_{j}^{\theta_{i}}\right)\right]$, the maximum envelopes $\left\{e^{\theta_{i}}(t)\right\}_{k=1}^{K}$ in each direction can be acquired;

(g) The mean value of the maximum envelopes in all directions is computed as $m(t)=\frac{1}{K} \sum_{k=1}^{K} e^{\theta_{i}}(t)$

(h) If $c_{i}(t)=z(t)-m(t)$ fulfills the stopping criterion for an IMF, apply the above procedure to $r_{i}(t)=z(t)-x_{i}(t)$ to calculate the residue and an IMF is obtained; otherwise, go back to step (b).

After decomposing each continuous variable into separate IMF groups and residuals using the NA-MEMD method, we reconstruct them by the frequency, duration, and magnitude. A $t$-test was performed on the means of each superimposed series in the IMFs, and if the means are not significantly different from zero, they will be aggregated as high-frequency series. The remaining IMFs are combined into lowfrequency series and the residual terms into trend series. Figures 4, 5, and 6 show the time series of the main variables for the high-frequency, low-frequency, and trend terms, respectively. The left axis represents the number of confirmed cases and deaths, and the right axis represents the EUA futures settlement prices.

Regarding the carbon price series, the high-frequency component has a relatively short period and usually fluctuates around zero, representing the effects 


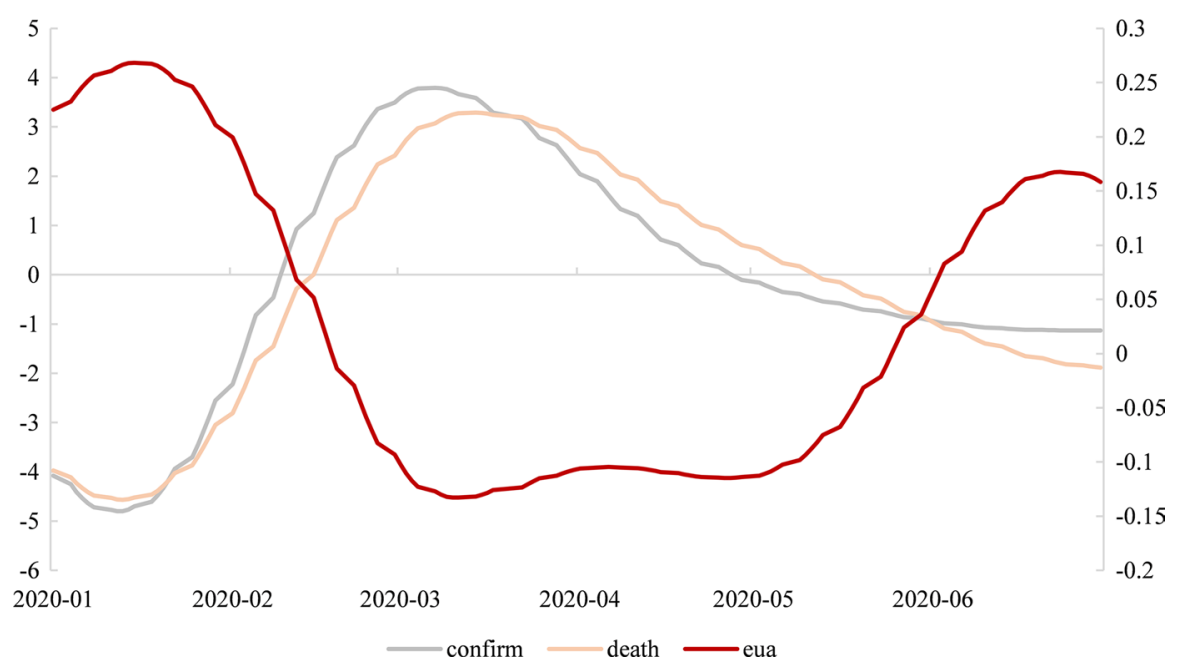

Fig. 5 Low-frequency results

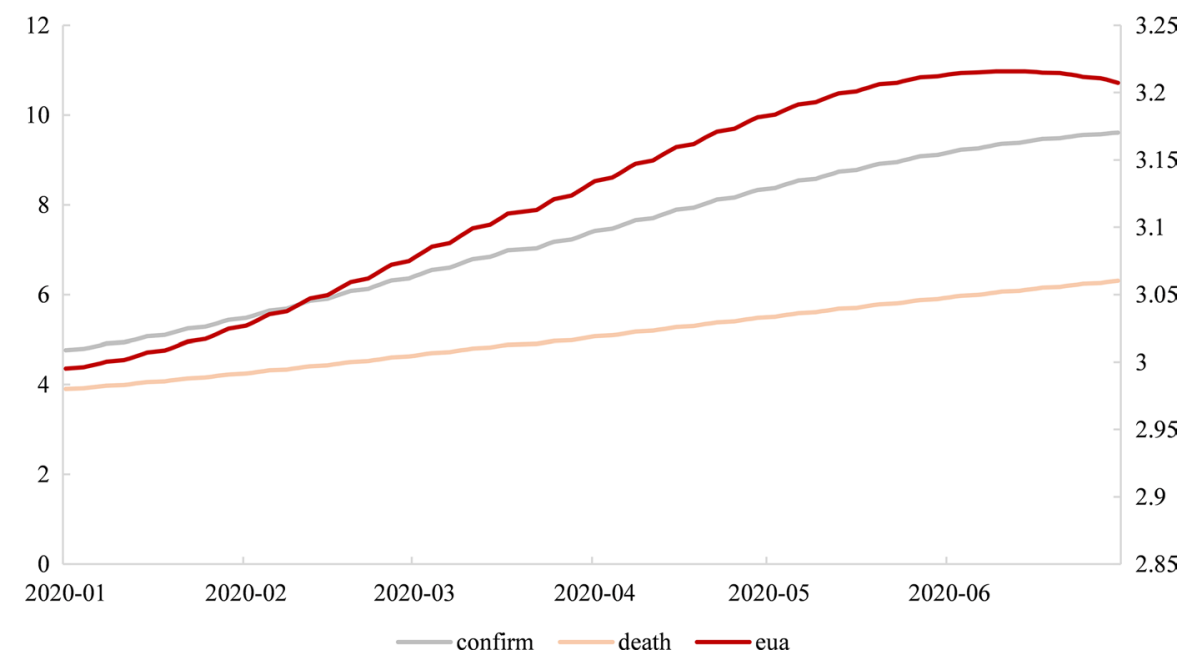

Fig. 6 Trend term results

of short-term variations in the carbon trading system caused by, for example, short-term market imbalances and speculation (Zhang 2008; Zhu et al. 2015). In contrast, the low-frequency component has a longer period and larger amplitude, reflecting the impact of major events on carbon prices, such as regulatory adjustments, information disclosure, international politics, and negotiations, and would gradually fall back to zero after the shock removal (Zhu et al. 2019). Finally, the trend term depicts the long-term equilibrium of the market, which is influenced 
Table 2 The impact of COVID-19 on carbon prices, baseline estimations

\begin{tabular}{|c|c|c|c|c|c|c|}
\hline & (1) еиа & (2) еиа & (3) еиа & (4) еиа & (5) еиа & (6) еиа \\
\hline Confirm & $\begin{array}{l}-0.0185^{* * *} \\
(-7.35)\end{array}$ & $\begin{array}{l}0.0709^{* * * *} \\
(6.24)\end{array}$ & $\begin{array}{l}0.0536^{* * *} \\
(5.01)\end{array}$ & & & \\
\hline Confirm $^{2}$ & & $\begin{array}{l}-0.0089^{\text {*** }} \\
(-7.79)\end{array}$ & $\begin{array}{l}-0.0037^{\text {*** }} \\
(-2.67)\end{array}$ & & & \\
\hline Death & & & & $\begin{array}{l}-0.0323^{* * *} \\
(-10.30)\end{array}$ & $\begin{array}{l}0.0603^{* * * *} \\
(6.26)\end{array}$ & $\begin{array}{l}0.0905^{* * *} \\
(6.75)\end{array}$ \\
\hline Death $^{2}$ & & & & & $\begin{array}{l}-0.0121^{* * *} \\
(-8.54)\end{array}$ & $\begin{array}{l}-0.0102^{* *} \\
(-7.79)\end{array}$ \\
\hline Stock & & & $\begin{array}{l}0.8617^{* * *} \\
(3.68)\end{array}$ & & & $\begin{array}{l}1.0267^{* * *} \\
(5.05)\end{array}$ \\
\hline Coal & & & $\begin{array}{l}0.3544^{*} \\
(1.97)\end{array}$ & & & $\begin{array}{l}0.2853^{* *} \\
(2.04)\end{array}$ \\
\hline Oil & & & $\begin{array}{l}0.1595^{* * *} \\
(2.88)\end{array}$ & & & $\begin{array}{l}0.0334 \\
(0.62)\end{array}$ \\
\hline Gas & & & $\begin{array}{l}-0.1565^{* * *} \\
(-3.09)\end{array}$ & & & $\begin{array}{l}-0.0835^{*} \\
(-1.76)\end{array}$ \\
\hline Surprise & & & $\begin{array}{l}0.0290^{* * *} \\
(4.12)\end{array}$ & & & $\begin{array}{l}0.0283^{* * *} \\
(4.86)\end{array}$ \\
\hline $\mathrm{N}$ & 128 & 128 & 128 & 128 & 128 & 128 \\
\hline$R^{2}$ & 0.15 & 0.35 & 0.75 & 0.34 & 0.59 & 0.75 \\
\hline
\end{tabular}

This table reports baseline estimations of COVID-19 on carbon prices. All variables are in natural logarithmic form. Robust standard errors are estimated. t-statistics are presented in parentheses. *, **, and *** represent significance levels of $10 \%, 5 \%$, and $1 \%$, respectively

by factors such as macroeconomic growth and energy prices, supply-side quota schemes, and related price stabilizers (Xu et al. 2019).

\section{Empirical results and analysis}

We conduct empirical tests using the time series data from January 24 to July 23, 2020. Table 2 shows the results of baseline regressions. Columns (1) to (3) consider the effect of the number of confirmed cases on the EUA price, and columns (4) to (6) observe the impacts of the number of deaths. The heteroscedasticity is corrected using the estimates of robust standard errors.

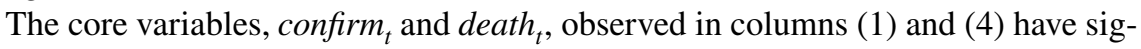
nificant and negative coefficients, indicating that carbon price decreases as the number of COVID-19 infected increases. When the number of confirmed cases (deaths) increases by $1 \%$, the EUA price decreases by $0.0185 \%(0.0323 \%)$. The coefficients reveal that the carbon price is more sensitive to an increase in the number of deaths, probably because the deaths suggest a further worsening of the pandemic. When adding the squares of confirm or death $_{t}$, the square term coefficients become significantly negative, indicating an inverted U-shaped relationship between the number of cases and carbon prices. The inverted U-shaped relationship suggests that during the 
pandemic, the EUA price increased and then decreased with the number of cases, probably because the EU ETS was not aware of the severity of the pandemic at the initial stage of the COVID-19 outbreak in early 2020. At that point, the EUA price was still rising because of the "European Green Deal" implemented by the EU in December 2019, presenting a lag in response to the COVID-19 outbreak. This result is consistent with Vasileiou et al.'s (2021) findings concerning the stock market, which showed that the market reacts irrationally and inefficiently to the available information over a given period. As the number of confirmed cases and deaths increased exponentially, the EUA price started to decrease, possibly for two reasons. In one aspect, the carbon price was discouraged by the shrinkage in the demand for carbon allowance, since the rapid spread of COVID-19 in Europe led to many shutdowns in manufacturing and transportation and a consequent reduction in carbon emissions. For another, as the stock markets in many European countries plummeted by more than $1 / 3$ within a short period following the pandemic and tight liquidity, the widespread panic further caused the EUA price to fall. ${ }^{13}$

In columns (3) and (6), we include control variables to enhance the explanatory power. The consideration of control variables does not change the inverted U-shaped relationship but decreases the absolute value of the core coefficients. The $R^{2}$ is significantly higher, implying that EUA prices are not only associated with negative shocks from the COVID-19 outbreak, but also closely related to energy prices, capital markets, and macroeconomic conditions. To be specific, the stock price $\left(\right.$ stock $\left._{t}\right)$ and the economic surprise index ( surprise $_{t}$ ) are positively correlated with the carbon prices. Together, they bore the adverse effects of the outbreak. Among the energy prices, the two traditional energy sources, namely coal $\left(\right.$ coal $\left._{t}\right)$ and oil $\left(\right.$ oil $\left._{t}\right)$, are significantly and positively related to the EUA prices, while natural gas $\left(\right.$ gas $\left._{t}\right)$ is significantly but negatively correlated with carbon prices. Theoritically the substitution effect of energy prices causes a negative impact of fossil energy prices and a positive impact of renewable energy prices on carbon prices (Zhu et al. 2019). ${ }^{14}$ However, during COVID-19, we witness a different situation. The shutdown of production during the pandemic caused an overall reduction in energy consumption and carbon emissions; hence, any energy price could not reduce the demand and price for carbon allowances. Moreover, while oil and gas prices declined sharply during the COVID-19 pandemic, the decrease in the former was mainly due to the supply shocks generated by the Saudi-Russian price war and demand shocks originated from the COVID-19 crisis; the latter was mainly attributed to warm winters, ample supplies, and intense competition in the industry (Hauser et al. 2020). Both were affected by factors different from the past; thus, it is understandable that their effects on the carbon market were not consistent with the theory.

\footnotetext{
13 Retrieved from http://www.tanjiaoyi.com/article-30814-1.html. Last accessed October 20, 2021.

14 In general, when fossil energy prices rise, power plants will reduce their use of these fossil energy sources and increase the use of cleaner energy sources. Hence, carbon emissions will decrease, and the carbon market will consequently reduce the demand for carbon allowances, leading to a decrease in the price of carbon. Conversely, when the price of clean energy increases, power plants will use cheaper fossil energy sources, which increases the price of carbon (Chevallier 2011).
} 
Table 3 The impact of COVID-19 on government policy, threshold estimations

\begin{tabular}{|c|c|c|c|c|c|c|c|}
\hline \multirow[t]{2}{*}{ Variable } & \multirow[t]{2}{*}{ Threshold } & \multicolumn{2}{|c|}{ Coefficient } & \multirow[t]{2}{*}{ Variable } & \multirow[t]{2}{*}{ Threshold } & \multicolumn{2}{|l|}{ Coefficient } \\
\hline & & Region 1 & Region 2 & & & Region 1 & Region 2 \\
\hline confirm & 7.2779 & $\begin{array}{l}5.1483^{* * *} \\
(73.04)\end{array}$ & $\begin{array}{l}7.4093^{* * *} \\
(185.93)\end{array}$ & death & 3.4340 & $\begin{array}{l}5.0790^{* * * *} \\
(68.08)\end{array}$ & $\begin{array}{l}7.3839^{* * *} \\
(182.87)\end{array}$ \\
\hline
\end{tabular}

This table reports threshold estimations. The number of bootstrap replications is 300 , the trimming proportion to estimate threshold is 0.01 , the number of grid points is 100 , and the number of initial sample seeds is 300. All variables are in natural logarithmic form. *, **, and *** represent significance levels of $10 \%, 5 \%$, and $1 \%$, respectively

\section{Further analysis}

In the baseline regression, we do not discuss the effect of government responses and fiscal policies. Due to a lack of experience, the COVID-19 pandemic was treated as common seasonal influenza at its early stage and did not attract much attention from the healthcare providers and government departments. Globally, current medical conditions, even with enormous financial and time investment, can only partially mitigate the spread of the COVID-19 pandemic. At this stage, allowing COVID-19 to dissipate on its own would not only cause short-term damage in the EU ETS but also generate long-term structural problems in the global economy. In fact, the governments strengthened their public policies to tackle the problems, but only after many lives and properties were lost. To discuss the role of recovery policies, we divide the main EU policies in response to the pandemic into two categories: government response and fiscal policies. The former is adjusted to the dynamics of the pandemic, while the latter has a clear start date (May 27, 2020).

\subsection{Policy effect}

A threshold model is used to examine the threshold at which the pandemic prevention was strengthened. Table 3 presents the empirical results of threshold regres-

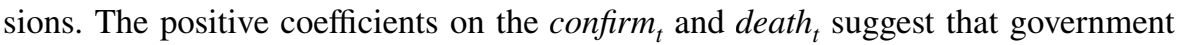
control measures were intensified as the spread of COVID-19 pandemic. Furthermore, when the number of confirmed cases and deaths (in natural logarithmic form) exceeded 7.28 and 3.43 , respectively, the coefficient of stringency $y_{t}$ increased more significantly. ${ }^{15}$

Thus, we consider March 3, 2020, when the member states cumulatively recorded 3170 confirmed cases and 86 deaths, as the starting date of the more stringent government responses $\left(\right.$ govern $\left._{t}\right)$. Table 4 shows the specific assignments of government responses $\left(\right.$ govern $\left._{t}\right)$ and fiscal policies $\left(\right.$ fiscal $\left._{t}\right)$.

\footnotetext{
${ }^{15} \mathrm{We}$ also use the death/ confirmed ratio $\left(d c_{t}\right)$ to conduct a robustness estimation. After consider $d c_{t}$ as the explanatory variable in Eq. (2), a threshold of 0.3943 could be obtained and matched to 25 February, which is close to our selected threshold day (3 March).
} 
Table 4 The value of govern and fiscal $_{t}$

\begin{tabular}{lll}
\hline & 0 & 1 \\
\hline govern $_{t}$ & $24 / 01 / 2020-02 / 03 / 2020$ & $03 / 03 / 2020-07 / 24 / 2020$ \\
iscal $_{t}$ & $24 / 01 / 2020-26 / 05 / 2020$ & $27 / 05 / 2020-07 / 24 / 2020$ \\
\hline
\end{tabular}

This table reports the value of govern $_{t}$ according to the threshold estimations and fiscal $_{t}$ according to the start date of the EU recovery plan.

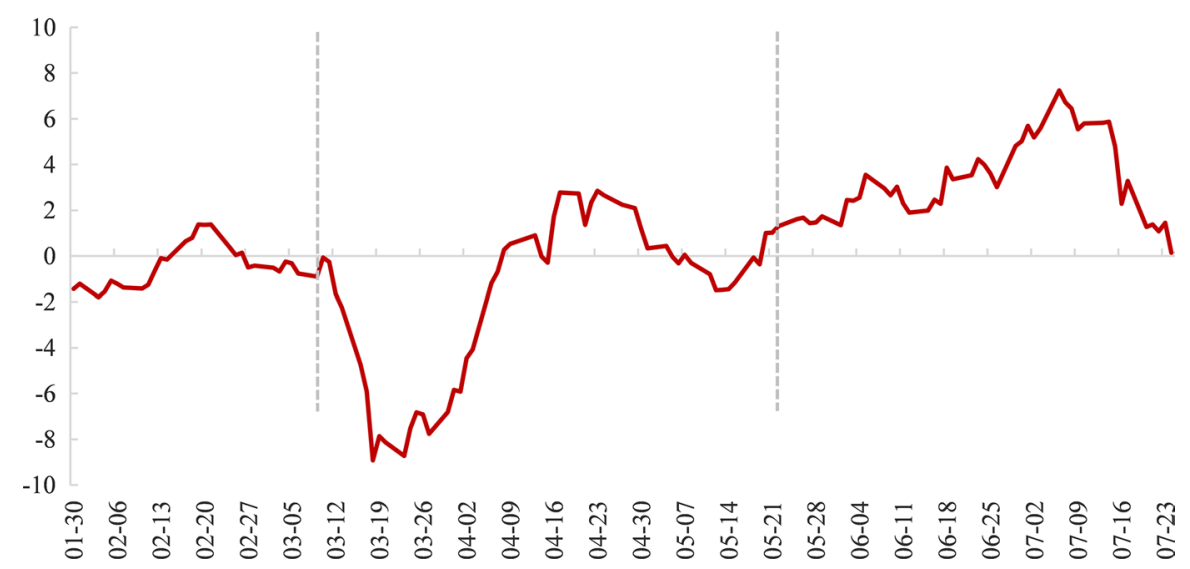

Fig. 7 The abnormal EUA prices

To have an overview on the policy impact of government responses and fiscal policies on carbon prices during the COVID-19, Fig. 7 plots the abnormal EUA prices by calculating the difference between the carbon price at the day $t$ and the average price from the day $(t-30)$ to $(t-10) .{ }^{16}$ The abnormal EUA price was negative first and then turn to positive from March to April. Although have been strengthened in early March, government responses began to function in the middle of April, suggesting a longer lead time of government responses and ETS recovery. Compared with government responses, fiscal policies made an immediate impact, as abnormal EUA prices experienced rapid recovery and increase after 27 May.

Table 5 shows the impact of government responses and fiscal policies on carbon prices. Considering that the potential collinearity between the Government Response Stringency index (stringency $)_{t}$ ) and the number of newly confirmed cases $\left(\right.$ confirm $\left._{t}\right)$ or deaths $\left(\right.$ death $\left._{t}\right)$, column (1) only analyzes the impact of stringency $y_{t}$ on carbon prices. Based on the regression results, the stringency ${ }_{t}$ is significantly and positively associated with the EUA prices. Columns (2) to (7) examine the impact of government responses $\left(\right.$ govern $_{t}$ ) and fiscal policies $\left(\right.$ fiscal $\left._{t}\right)$ on the carbon prices, considering either the confirm $_{t}$ or death ${ }_{t}$ as the explanatory variables. The results show that

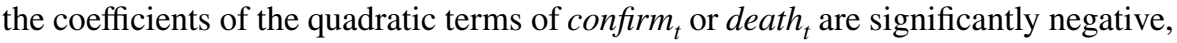

16 The calculation of abnormal prices refers to the principle of event study. 
Table 5 The impact of government policy on carbon prices

\begin{tabular}{|c|c|c|c|c|c|c|c|}
\hline & (1) еиа & (2) еиа & (3) еиа & (4) еиа & (5) еиа & (6) еиа & (7) еиа \\
\hline Stringency & $\begin{array}{l}0.0804^{\text {**** }} \\
(3.41)\end{array}$ & & & & & & \\
\hline Govern & & $\begin{array}{l}0.1787^{* * * *} \\
(3.56)\end{array}$ & & $\begin{array}{l}0.1584^{* * * *} \\
(2.94)\end{array}$ & $\begin{array}{l}0.1073^{* *} \\
(2.45)\end{array}$ & & $\begin{array}{l}0.1066^{* *} \\
(2.19)\end{array}$ \\
\hline Fiscal & & & $\begin{array}{l}0.0681^{\text {必冰 }} \\
(3.15)\end{array}$ & $\begin{array}{l}0.0681^{\text {**** }} \\
(3.15)\end{array}$ & & $\begin{array}{l}0.0116 \\
(0.52)\end{array}$ & $\begin{array}{l}0.0554^{\text {**** }} \\
(2.66)\end{array}$ \\
\hline Confirm & & $\begin{array}{l}0.0385^{\text {*** }} \\
(5.22)\end{array}$ & 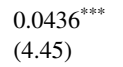 & $\begin{array}{l}0.0352^{\text {***k }} \\
(4.41)\end{array}$ & & & \\
\hline Confirm $^{2}$ & & $\begin{array}{l}-0.0039^{\text {**** }} \\
(-3.25)\end{array}$ & $\begin{array}{l}-0.0030^{\text {*** }} \\
(-2.35)\end{array}$ & $\begin{array}{l}-0.0035^{* * * *} \\
(-2.87)\end{array}$ & & & \\
\hline Death & & & & & $\begin{array}{l}0.0575^{* * *} \\
(4.89)\end{array}$ & $\begin{array}{l}0.0872^{* * * *} \\
(5.52)\end{array}$ & $\begin{array}{l}0.0571^{* * * *} \\
(4.66)\end{array}$ \\
\hline Death $^{2}$ & & & & & $\begin{array}{l}-0.0077^{* * * *} \\
(-6.80)\end{array}$ & $\begin{array}{l}-0.0098^{* * * *} \\
(-6.27)\end{array}$ & $\begin{array}{l}-0.0077^{\text {*** }} \\
(-6.19)\end{array}$ \\
\hline $\mathrm{N}$ & 128 & 128 & 128 & 128 & 128 & 128 & 128 \\
\hline$R^{2}$ & 0.72 & 0.79 & 0.77 & 0.79 & 0.80 & 0.80 & 0.80 \\
\hline
\end{tabular}

As Table 2, only the results of the core variables are shown

still supporting an inverted U-shaped relationship between the number of cases and the EUA prices. Furthermore, the absolute value of confirm $_{t}$ coefficients decreases slightly compared to that in Table 2 , signifying that the spread of the pandemic still causes a decrease in the EUA price; however, owing to effective policy support, it is of less degree.

We constantly obtain positive and significant coefficients when incorporating the government responses ( govern $_{t}$ ) into columns (2) and (5); however, when only the fiscal policies ( fiscal $_{t}$ ) are included in columns (3) and (6), the coefficients are positive but not consistently significant. In columns (4) and (7), when we consider both the policy dummy variables, namely government responses $\left(\right.$ gover $\left._{t}\right)$ and fiscal policies $\left(\right.$ fiscal $\left._{t}\right),{ }^{17}$ their coefficients are significant and positive. The coefficients of govern $_{t}$ are always greater than that of fiscal $_{t}$, suggesting that government responses have a better and positive impact on the EUA price than fiscal policies. Although the active government response might not completely compensate for the negative impact of COVID-19 on the EUA price, it would effectively reclaim some of the losses. This also explains why the EUA price only experienced a short term rather than sustained plunge from March to April 2020. The EU governments' prevention and control measures and recovery policies implemented since the beginning of March 2020 have had a positive effect on the recovery of the carbon price. After the end of May, government responses and fiscal policies advanced together for the further development of green recovery and EU ETS.

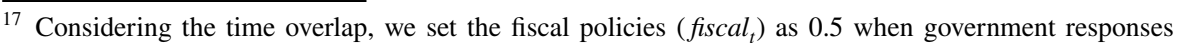
$\left(\right.$ govern $_{t}$ ) equals to 1 (hereinafter same).
} 
Table 6 The impact of COVID-19 and government policy on carbon prices at multiscales

\begin{tabular}{|c|c|c|c|c|c|}
\hline & \multirow{2}{*}{$\begin{array}{l}\text { Trend term } \\
\text { (1) eua }\end{array}$} & \multicolumn{2}{|c|}{ Low-frequency } & \multicolumn{2}{|c|}{ High-frequency } \\
\hline & & (2) еиа & (3) еиа & (4) еиа & (5) еиа \\
\hline Govern & $\begin{array}{l}0.1011 * * * \\
(15.97)\end{array}$ & $\begin{array}{l}0.0140^{* * *} \\
(3.30)\end{array}$ & $\begin{array}{l}0.0695^{* *} \\
(2.05)\end{array}$ & $\begin{array}{l}0.0268^{* *} \\
(2.17)\end{array}$ & $\begin{array}{l}0.0225^{*} \\
(1.86)\end{array}$ \\
\hline Fiscal & $\begin{array}{l}0.1441 * * * \\
(42.27)\end{array}$ & $\begin{array}{l}0.0082 \\
(1.41)\end{array}$ & $\begin{array}{l}0.0466^{* * *} \\
(2.85)\end{array}$ & $\begin{array}{l}0.0111 \\
(1.53)\end{array}$ & $\begin{array}{l}0.0075 \\
(1.07)\end{array}$ \\
\hline Confirm & & $\begin{array}{l}0.2087^{* * *} \\
(14.07)\end{array}$ & & $\begin{array}{l}0.0046 \\
(0.90)\end{array}$ & \\
\hline Confirm $^{2}$ & & $\begin{array}{l}0.0008^{* * *} \\
(2.14)\end{array}$ & & $\begin{array}{l}0.0059^{*} \\
(1.69)\end{array}$ & \\
\hline Death & & & $\begin{array}{l}-0.1973^{* * *} \\
(-10.20)\end{array}$ & & $\begin{array}{l}0.0047 \\
(0.26)\end{array}$ \\
\hline Death $^{2}$ & & & $\begin{array}{l}0.0080^{* * *} \\
(7.07)\end{array}$ & & $\begin{array}{l}0.0220 \\
(0.90)\end{array}$ \\
\hline $\mathrm{N}$ & 128 & 128 & 128 & 128 & 128 \\
\hline$R^{2}$ & 0.84 & 0.99 & 0.91 & 0.76 & 0.89 \\
\hline
\end{tabular}

As Table 2, only the results of the core variables are shown.

\subsection{Multiscale analysis}

Both carbon prices and their affecting factors consist of different periodic components, thus being non-stationary and non-linear, but our previous study ignores it. After using the NA-MEMD method to capture the multiscale characteristics of carbon price volatility and pandemic spread, we observe the impact of government responses and fiscal policies on carbon prices at different time scales in Table 6. Column (1) exhibits the driving mechanism of carbon prices on the trend term. ${ }^{18}$ Both the government responses $\left(\right.$ gover $\left._{t}\right)$ and fiscal policies $\left(\right.$ fiscal $_{t}$ ) have significantly positive coefficients, but with small differences in the absolute values. This indicates that in the long term, recovery policies bring benefit to the recovery and equilibrium of carbon market.

Second, columns (2) and (3) show the results for the low-frequency series. The carbon price has a significant U-shaped relationship with the number of cases in the medium term: when the case $_{t}$ is low, the carbon price decreases with the number of infections, while when the case $e_{t}$ increases to a certain number, the carbon price also improves. The positive coefficients of government responses $\left(\right.$ govern $\left._{t}\right)$ and fiscal policies $\left(\right.$ fiscal $\left._{t}\right)$ also suggest that due to the policy intervention, the COVID-19 recession would not cause a long-lasting decrease in the carbon market efficiency. ${ }^{19}$ This demonstrates the stimulating effect of recovery policies, that is, the government

\footnotetext{
18 Considering that the trend term of the carbon price reflects the long-term equilibrium of the carbon market, we do not include the short-term variable $\left(\right.$ case $\left._{t}\right)$ in the explanatory variables.

19 Retrieved from https://www.climatechangenews.com/2021/03/24/carbon-markets-proved-resilientcoronavirus-pandemic/. Last accessed October 20, 2021.
} 
would only take proactive steps against the pandemic when the number of infections exceeds a certain level. By preventing the pandemic spread, policies help to restore the carbon price through various possible channels in the medium term. First, on the demand side, production and life revival have led to a gradual recovery in the demand for carbon allowance from emission-controlled companies. Second, on the supply side, the EU carbon allowance has been gradually tightened, increasing the carbon price. Third, on the liquidity aspect, central banks cut the interest rate, and thus, a large amount of capital has flowed into the commodity markets. ${ }^{20}$ Fourth, post-pandemic economic recovery and the proposed European Green New Deal at the end of 2019 boost participants' confidence in future climate policy. For a single type of policy, government responses $\left(\right.$ govern $_{t}$ ) are more effective and significant to EU ETS recovery than the fiscal policies ( fiscal $_{t}$ ) during the medium term.

Finally, columns (4) and (5) demonstrate the mechanism driving the high-frequency series of carbon prices. Here, the relationship between the carbon price and the number of cases is unclear. Figure 2 shows that when the carbon price is low, the trading volume is high, indicating the speculation and temporary imbalances of EU ETS in the short term. Therefore, the pandemic is not the dominant factor for the short-term EUA prices. The coefficients of government responses $\left(\right.$ govern $\left._{t}\right)$ are positive and significant, while that of fiscal policies $\left(\right.$ fiscal $\left._{t}\right)$ is insignificant, implying that the short-term rebound in EUA prices is mainly driven by the economics of government responses (govern $)^{\text {). }}$.

From the NA-MEMD model, we know that the high-frequency series identifies the impact of the short-term fluctuations in supply and demand and speculation on carbon prices, the low-frequency observes the impact of major events, and the trend term considers the impact of the long-term equilibrium. From the regression coefficients and their economic implications for the three time scales presented in Table 6, we conclude that: (1) Regarding the impact of the pandemic on the EUA price, the carbon price fluctuates in the short term with the number of new confirmations $\left(\right.$ confirm $\left._{t}\right)$ or deaths $\left(\right.$ death $\left._{t}\right)$, but gradually recovers in the long term as a result of policy incentives. (2) As for the impact of policies, carbon prices are improved by the government responses that corrects the supply-demand imbalances and speculation in the short and medium term. Further, government responses and fiscal policies stabilize the macroeconomy and promoting the long-term equilibrium of EU ETS.

These conclusions are consistent with the intuition of Figs. 4, 5, 6, and 7, where the EUA price stopped decreasing by the end of March 2020 and increased dramatically from the end of May; the former is due to more stringent government responses to control the pandemic, and the latter is the comprehensive effect of both the government responses and fiscal policies. In the EU ETS, EUA prices first fell sharply during the emergence of the COVID-19 outbreak. When the government started to strengthen control of the pandemic, the government responses first exerted a "stop-loss" effect on the carbon price and then maintain and promote the development of the carbon market alongside the fiscal policies. In the post-pandemic era,

${ }^{20}$ Retrieved from http://www.tanjiaoyi.com/article-31605-1.html. Last accessed October 20, 2021. 
short-term recovery and long-term development should be combined to find ways to turn the current health crisis into an opportunity for mitigating climate change (Zhu and Zhang 2020).

\section{Conclusion and discussion}

In this study, we analyze the impact of the COVID-19 pandemic and recovery policies on EU ETS. In the original time scales, we find that: (1) The EUA prices have an inverted U-shaped relationship with the number of cases. The EUA prices increase and then decrease with the number of cases and are more sensitive to the increasing number of deaths. In addition to the negative shocks of the pandemic, economic factors and energy prices also affected the EUA prices. (2) After dividing the EU recovery policies into two types (government responses and fiscal policies), government responses play a greater role in reviving carbon prices than fiscal policies.

Using the NA-MEMD to decompose all the continuous variables into three time series, namely high-frequency (short-term), low-frequency (medium-term), and trend terms (long-term), we observe that: (1) In the low-frequency time series, the EUA price has a U-shaped relationship with the number of cases: the carbon price fluctuated in the short term with the number of new confirmed cases (or deaths) but gradually recovered due to the policy incentives. (2) In the low-frequency time series, supply-demand imbalances and speculation appear in the EU ETS. (3) Government responses have a "stop-loss" effect in the short and medium term, and then working alongside fiscal policies, sustain and promote the development of the EU ETS. Government responses are likely to guide the EUA price back to pre-pandemic levels by increasing the emission demand, curtailing allowance supply, increasing market liquidity, and boosting market confidence. In the short term, government responses have a "stop-loss" effect by correcting short-term supply and demand and speculative behavior. In the long term, government responses and fiscal policies together maintain and promote the EU ETS by promoting the macroeconomy and long-term equilibrium.

These findings have important implications. On the one hand, the government prevention and control measures can not only directly alleviate the COVID-19 outbreak but also indirectly generate economic benefits by providing opportunities to carbon markets and climate change. Consensus on the net economic impact of government prevention and control can motivate governments to design more effective response measures. On the other hand, the information on dynamic carbon price drivers can be used for regulatory and investment purposes. When EU ETS meets COVID-19, knowledge of the pandemic and policy impact on carbon price dynamics facilitates our analysis of short- and long-term price volatility. In the postpandemic era, short- and long-term government policies should be synergized to explore the possibility of converting the current health crisis into opportunities for mitigating climate change.

Specifically, in the post-COVID-19 era, there might be two practical ways for green recover. (1) For the relatively lower-middle-income countries in EU, fiscal 
policymakers should still pay attention to ecological protection and pollution control projects. These projects can boost employment advantages in a short period of time (especially lower the employment access conditions). (2) For the upper-middleincome countries, in addition to the financial stimulus of short-term utility, fiscal policymakers should allocate a portion of their financial expenditure to the R\&D sector of green industries. This action might not have an immediate effect on the economy or the environment, but it has unpredictable potential in the long run.

This study consider the impact of COVID-19 and government responses on the EU carbon price, but with several limitations. First, while government responses and fiscal policies have been continuously implemented, we have not examined their dynamic effects. Second, since we considered the recovery policies of the EU as a whole, the resilience of individual countries during the COVID-19 pandemic is ignored. Finally, we concentrate on green recovery at the EU level, ignoring the carbon trading systems present in emerging economies such as China. In future studies, the long-term and comprehensive effects of COVID-19 and its recovery still need to be explored.

Author contributions HD was involved in conceptualization; data curation; formal analysis; methodology; writing — original draft preparation. XT contributed to funding acquisition; supervision; methodology. SC was involved in supervision; methodology. YL contributed to funding acquisition; data curation; formal analysis; writing-review and editing.

Funding The paper was supported by the Youth Academic Team in Humanities and Social Sciences of Wuhan University [Grant Numbers 4103-413100001], and the Graduate Project of Wuhan University [Grant Numbers 1201-413100137].

\section{Declarations}

Conflict of interest Author Hanmin Dong declares that she has no conflict of interest. Author Xiujie Tan declares that he has no conflict of interest. Author Si Cheng declares that she has no conflict of interest. Author Yishuang Liu declares that he has no conflict of interest.

Data availability All the data sets used in the current study are available on Wind, CSMAR and the Oxford COVID-19 Government Response Tracker Database (OxCGRT).

\section{References}

Aatola P, Ollikainen M, Toppinen A (2013) Price determination in the EU ETS market: theory and econometric analysis with market fundamentals. Energy Econ 36:380-395. https://doi.org/10. 1016/j.eneco.2012.09.009

Al-Awadhi AM, Alsaifi K, Al-Awadhi A, Alhammadi S (2020) Death and contagious infectious diseases: impact of the COVID-19 virus on stock market returns. J Behav Exp Financ 27:100326. https://doi. org/10.1016/j.jbef.2020.100326

Alberola E, Chevallier J, Chèze B (2008) Price drivers and structural breaks in European carbon prices 2005-2007. Energy Policy 36(2):787-797. https://doi.org/10.1016/j.enpol.2007.10.029 
Alberola E, Arslan Y, Cheng G, Moessner R (2021) Fiscal response to the COVID-19 crisis in advanced and emerging market economies. Pac Econ Rev 26(4):459-468. https://doi.org/10.1111/1468-0106. 12370

Anderson RM, Heesterbeek H, Klinkenberg D, Hollingsworth TD (2020) How will country-based mitigation measures influence the course of the COVID-19 epidemic? Lancet 395(10228):931-934. https://doi.org/10.1016/S0140-6736(20)30567-5

Ashraf BN (2020a) Economic impact of government interventions during the COVID-19 pandemic: International evidence from financial markets. J Behav Exp Financ 27:100371. https://doi.org/10. 1016/j.jbef.2020.100371

Ashraf BN (2020b) Stock markets' reaction to COVID-19: cases or fatalities? Res Int Bus Financ 54:101249. https://doi.org/10.1016/j.ribaf.2020.101249

Ashraf BN (2021) Stock markets' reaction to COVID-19: moderating role of national culture. Financ Res Lett 41:101857. https://doi.org/10.1016/j.frl.2020.101857

Azarova V, Mier M (2020) MSR under exogenous shock: the case of COVID-19 pandemic. Retrieved from https://www.econstor.eu/handle/10419/226802. Last accessed October 20, 2021

Baker SR, Bloom N, Davis SJ, Kost K, Sammon M, Viratyosin T (2020) The unprecedented stock market reaction to COVID-19. Rev Asset Pricing Stud 10(4):742-758. https://doi.org/10.1007/ s11869-020-00898-4

Baldwin R, Di Mauro BW (2020) Economics in the time of COVID-19. Retrieved from https://fonda zionecerm.it/wp-content/uploads/2020/03/CEPR-Economics-in-the-time-of-COVID-19_-A-neweBook.pdf. Last accessed October 20, 2021

Balsalobre-Lorente D, Driha OM, Bekun FV, Sinha A, Adedoyin FF (2020) Consequences of COVID19 on the social isolation of the Chinese economy: accounting for the role of reduction in carbon emissions. Air Qual Atmos Health 13(12):1439-1451. https://doi.org/10.1007/s11869-020-00898-4

Bargain O, Aminjonov U (2020) Trust and compliance to public health policies in times of COVID-19. J Public Econ 192:104316. https://doi.org/10.1016/j.jpubeco.2020.104316

Barrot JN, Grassi B, Sauvagnat J (2020) Estimating the costs and benefits of mandated business closures in a pandemic. Retrieved from https://ssrn.com/abstract=3603989. Last accessed October 20, 2021

Batten JA, Maddox GE, Young MR (2021) Does weather, or energy prices, affect carbon prices? Energy Econ 96:105016. https://doi.org/10.1016/j.eneco.2020.105016

Benz E, Trück S (2009) Modeling the price dynamics of $\mathrm{CO}_{2}$ emission allowances. Energy Econ 31(1):415. https://doi.org/10.1016/j.eneco.2008.07.003

Bocklet J (2020) The reformed EU ETS in times of economic crises: The case of the COVID-19 pandemic. Retrieved from https://www.ewi.uni-koeln.de/cms/wp-content/uploads/2020/12/EWI_WP_ 20-10_The_Reformed_EU_ETS_in_Times_of_Economic_Crises_Bocklet.pdf. Last accessed October 20, 2021

Boersen A, Scholtens B (2014) The relationship between European electricity markets and emission allowance futures prices in phase II of the EU (European Union) emission trading scheme. Energy 74:585-594. https://doi.org/10.1016/j.energy.2014.07.024

Brauner JM, Mindermann S, Sharma M, Johnston D, Salvatier J, Gavenčiak T, Stephenson AB, Leech G, Altman G, Mikulik V, Norman AJ (2021) Inferring the effectiveness of government interventions against COVID-19. Science. https://doi.org/10.1126/science.abd9338

Bruninx K, Ovaere M (2020) Estimating the impact of COVID-19 on emissions and emission allowance prices under EU ETS. Retrieved from https://www.iaee.org/en/publications/newsletterdl.aspx?id= 881. Last accessed October 20, 2021

Bruninx K, Ovaere M (2021) Waterbed leakage drives EU ETS emissions: COVID-19, the Green Deal \& the recovery plan. Retrieved from https://www.researchsquare.com/article/rs-270917/latest.pdf. Last accessed October 20, 2021

Chai S, Zhou P (2018) The Minimum-CVaR strategy with semi-parametric estimation in carbon market hedging problems. Energy Econ 76:64-75. https://doi.org/10.1016/j.eneco.2018.09.024

Chakraborty P, Jayachandran S, Padalkar P, Sitlhou L, Chakraborty S, Kar R, Bhaumik S, Srivastava M (2020) Exposure to nitrogen dioxide (NO 2) from vehicular emission could increase the COVID-19 pandemic fatality in India: a perspective. Bull Environ Contamin Toxicol 105(2):198-204. https:// doi.org/10.1007/s00128-020-02937-3

Chang CP, Feng GF, Zheng M (2021) Government fighting pandemic, stock market return, and COVID19 virus outbreak. Emerg Mark Financ Trade. https://doi.org/10.1080/1540496X.2021.1873129

Cheng BS (1995) An investigation of cointegration and causality between energy consumption and economic growth. J Energy Dev 21(1):73-84 
Chevallier J (2009) Carbon futures and macroeconomic risk factors: a view from the EU ETS. Energy Econ 31(4):614-625. https://doi.org/10.1016/j.eneco.2009.02.008

Chevallier J (2011) A model of carbon price interactions with macroeconomic and energy dynamics. Energy Econ 33(6):1295-1312. https://doi.org/10.1016/j.eneco.2011.07.012

Chudik A, Mohaddes K, Raissi M (2021) COVID-19 fiscal support and its effectiveness. Econ Lett. https://doi.org/10.1016/j.econlet.2021.109939

Christiansen AC, Arvanitakis A, Tangen K, Hasselknippe H (2005) Price determinants in the EU emissions trading scheme. Climate Policy 5(1):15-30. https://doi.org/10.1080/14693062.2005. 9685538

Creti A, Jouvet PA, Mignon V (2012) Carbon price drivers: phase I versus phase II equilibrium? Energy Econ 34(1):327-334. https://doi.org/10.1016/j.eneco.2011.11.001

David SA, Inácio CM Jr, Machado J (2021) The recovery of global stock markets indices after impacts due to pandemics. Res Int Bus Financ 55:101335. https://doi.org/10.1016/j.ribaf.2020.101335

Deeney P, Cummins M, Dowling M, Smeaton AF (2016) Influences from the European Parliament on EU emissions prices. Energy Policy 88:561-572. https://doi.org/10.1016/j.enpol.2015.06.026

Devpura N, Narayan PK (2020) Hourly oil price volatility: the role of COVID-19. Energy Res Lett 1(2):13683. https://doi.org/10.46557/001c.13683

Dutta A, Bouri E, Noor MH (2018) Return and volatility linkages between CO2 emission and clean energy stock prices. Energy 164:803-810. https://doi.org/10.1016/j.energy.2018.09.055

Elkerbout M, Zetterberg L (2020) Can the EU ETS weather the impact of COVID-19? Retrieved from http://aei.pitt.edu/103369/. Last accessed October 20, 2021

Elliott RJ, Schumacher I, Withagen C (2020) Suggestions for a COVID-19 post-pandemic research agenda in environmental economics. Environ Resour Econ 76(4):1187-1213. https://doi.org/10. 1007/s10640-020-00478-1

Forster PM, Forster HI, Evans MJ, Gidden MJ, Jones CD, Keller CA, Lamboll RD, Le Quéré C, Rogelj J, Rosen D, Schleussner CF (2020) Current and future global climate impacts resulting from COVID-19. Nat Clim Change 10(10):913-919. https://doi.org/10.1038/s41558-020-0883-0

Gardiner B (2020) Why COVID-19 will end up harming the environment. Retrieved from https:// www.nationalgeographic.com/science/article/why-covid-19-will-end-up-harming-the-envir onment. Last accessed October 20, 2021

Gerlagh R, Heijmans RJ, Rosendahl KE (2020) COVID-19 tests the market stability reserve. Environ Resour Econ 76(4):855-865. https://doi.org/10.1007/s10640-020-00441-0

Gil-Alana LA, Monge M (2020) Crude oil prices and COVID-19: persistence of the shock. Energy Res Lett 1(1):13200. https://doi.org/10.46557/001c.13200

Gillingham KT, Knittel CR, Li J, Ovaere M, Reguant M (2020) The short-run and long-run effects of Covid-19 on energy and the environment. Joule 4(7):1337-1341. https://doi.org/10.1016/j.joule. 2020.06 .010

Goodell JW (2020) COVID-19 and finance: agendas for future research. Financ Res Lett 35:101512. https://doi.org/10.1016/j.frl.2020.101512

Gu X, Ying S, Zhang W, Tao Y (2020) How do firms respond to COVID-19? First evidence from Suzhou, China. Emerg Markets Finance Trade 56(10):2181-2197. https://doi.org/10.1080/15404 96X.2020.1789455

Haldar A, Sethi N (2020) The effect of country-level factors and government intervention on the incidence of COVID-19. Asian Econ Lett 1(2):17804. https://doi.org/10.46557/001c.17804

Hale T, Petherick A, Phillips T, Webster S (2020) Variation in government responses to COVID-19. Retrieved from https://www.bsg.ox.ac.uk/sites/default/files/2020-09/BSG-WP-2020-032-v7.0. pdf. Last accessed October 20, 2021

Hansen BE (1999) Threshold effects in non-dynamic panels: estimation, testing, and inference. J Econom 93(2):345-368. https://doi.org/10.1016/S0304-4076(99)00025-1

Haug N, Geyrhofer L, Londei A, Dervic E, Desvars-Larrive A, Loreto V, Pinior B, Thurner S, Klimek P (2020) Ranking the effectiveness of worldwide COVID-19 government interventions. Nat Human Behav 4(12):1303-1312. https://doi.org/10.1038/s41562-020-01009-0

Hauser P, Anke CP, López JG, Möst D, Scharf H, Schönheit D, Schreiber S (2020) The impact of the COVID-19 crisis on energy prices in comparison to the 2008 financial crisis. Retrieved from https://www.iaee.org/en/publications/newsletterdl.aspx?id=899. Last accessed October 20, 2021 
Hellewell J, Abbott S, Gimma A, Bosse NI, Jarvis CI, Russell TW, Munday JD, Kucharski AJ, Edmunds WJ, Sun F, Flasche S (2020) Feasibility of controlling COVID-19 outbreaks by isolation of cases and contacts. Lancet Glob Health 8(4):e488-e496. https://doi.org/10.1016/S2214-109X(20)30074-7

Hintermann B (2010) Allowance price drivers in the first phase of the EU ETS. J Environ Econ Manag 59(1):43-56. https://doi.org/10.1016/j.jeem.2009.07.002

Huang NE, Shen Z, Long SR, Wu MC, Shih HH, Zheng Q, Yen NC, Tung CC, Liu HH (1998) The empirical mode decomposition and the Hilbert spectrum for nonlinear and non-stationary time series analysis. Proceedings of the Royal Society of London. Series A Math Phys Eng Sci 454(1971):903-995. https://doi.org/10.1098/rspa.1998.0193

IEA (2020). Global energy review 2020. Retrieved from https://www.iea.org/reports/global-energyreview-2020. Last accessed October 20, 2021

Iyke BN (2020) Economic policy uncertainty in times of COVID-19 pandemic. Asian Econ Lett 1(2):17665. https://doi.org/10.46557/001c. 17665

Keppler JH, Mansanet-Bataller M (2010) Causalities between $\mathrm{CO}_{2}$, electricity, and other energy variables during phase I and phase II of the EU ETS. Energy Policy 38(7):3329-3341. https://doi.org/ 10.1016/j.enpol.2010.02.004

Kim HS, Koo WW (2010) Factors affecting the carbon allowance market in the US. Energy Policy 38(4):1879-1884. https://doi.org/10.1016/j.enpol.2009.11.066

Klemeš JJ, Van Fan Y, Tan RR, Jiang P (2020) Minimising the present and future plastic waste, energy and environmental footprints related to COVID-19. Renew Sustain Energy Rev 127:109883. https:// doi.org/10.1016/j.rser.2020.109883

Le Quéré C, Jackson RB, Jones MW, Smith AJ, Abernethy S, Andrew RM, De-Gol AJ, Willis DR, Shan Y, Canadell JG, Friedlingstein P (2020) Temporary reduction in daily global CO 2 emissions during the COVID-19 forced confinement. Nat Clim Change 10(7):647-653. https://doi.org/10.1038/ s41558-020-0797-x

Malliet P, Reynès F, Landa G, Hamdi-Cherif M, Saussay A (2020) Assessing short-term and longterm economic and environmental effects of the COVID-19 crisis in France. Environ Resour Econ 76(4):867-883. https://doi.org/10.1007/s10640-020-00488-z

Mansanet-Bataller M, Pardo A, Valor E (2007) $\mathrm{CO}_{2}$ prices, energy and weather. Energy J. https://doi.org/ 10.5547/ISSN0195-6574-EJ-Vol28-No3-5

Mills CE, Robins JM, Lipsitch M (2004) Transmissibility of 1918 pandemic influenza. Nature 432(7019):904-906. https://doi.org/10.1038/nature03063

Mintz-Woo K, Dennig F, Liu H, Schinko T (2020) Carbon pricing and COVID-19. Clim Policy. https:// doi.org/10.1080/14693062.2020.1831432

Mishra AK, Rath BN, Dash AK (2020) Does the Indian financial market nosedive because of the COVID-19 outbreak, in comparison to after demonetisation and the GST? Emerg Mark Financ Trade 56(10):2162-2180. https://doi.org/10.1080/1540496X.2020.1785425

Norouzi N, de Rubens GZ, Choupanpiesheh S, Enevoldsen P (2020) When pandemics impact economies and climate change: exploring the impacts of COVID-19 on oil and electricity demand in China. Energy Res Soc Sci 68:101654. https://doi.org/10.1016/j.erss.2020.101654

Obergassel W, Hermwille L, Oberthür S (2020) Harnessing international climate governance to drive a sustainable recovery from the COVID-19 pandemic. Clim Policy. https://doi.org/10.1080/14693062. 2020.1835603

Ou S, He X, Ji W, Chen W, Sui L, Gan Y, Lu Z, Lin Z, Deng S, Przesmitzki S, Bouchard J (2020) Machine learning model to project the impact of COVID-19 on US motor gasoline demand. Nat Energy 5(9):666-673. https://doi.org/10.1038/s41560-020-0662-1

Phan D, Narayan PK (2020) Country responses and the reaction of the stock market to COVID-19-A preliminary exposition. Emerg Mark Financ Trade 56(10):2138-2150. https://doi.org/10.1080/ 1540496X.2020.1784719

Ran Q, Lee SY, Moore JC, Min C, Dong W (2021) Economic shock in a climate scenario and its impact on surface temperatures. Earth's Fut 9(6):e2021EF002061. https://doi.org/10.1029/2021EF002061

Rehman N, Mandic DP (2010) Multivariate empirical mode decomposition. Proc Royal Soc A Math Phys Eng Sci 466(2117):1291-1302. https://doi.org/10.1098/rspa.2009.0502

Sartzetakis ES (2021) Green bonds as an instrument to finance low carbon transition. Econ Chang Restruct 54(3):755-779. https://doi.org/10.1007/s10644-020-09266-9

Shaikh I (2021) Impact of COVID-19 pandemic on the energy markets. Econ Chang Restruct. https://doi. org/10.1007/s10644-021-09320-0 
Shan Y, Ou J, Wang D, Zeng Z, Zhang S, Guan D, Hubacek K (2021) Impacts of COVID-19 and fiscal stimuli on global emissions and the Paris Agreement. Nat Clim Chang 11(3):200-206. https://doi. org/10.1038/s41558-020-00977-5

Shi X, Cheong TS, Zhou M (2021) COVID-19 and global supply chain configuration: economic and emissions impacts of Australia-China trade disruptions. Front Public Health. https://doi.org/10. 3389/fpubh.2021.752481

Steffen B, Egli F, Pahle M, Schmidt TS (2020) Navigating the clean energy transition in the COVID-19 crisis. Joule 4(6):1137-1141. https://doi.org/10.1016/j.joule.2020.04.011

Sun Y, Wu M, Zeng X, Peng Z (2021) The impact of COVID-19 on the Chinese stock market: sentimental or substantial? Financ Res Lett 38:101838. https://doi.org/10.1016/j.frl.2020.101838

Tahir MB, Batool A (2020) COVID-19: Healthy environmental impact for public safety and menaces oil market. Sci Total Environ 740:140054. https://doi.org/10.1016/j.scitotenv.2020.140054

Takahashi H, Yamada K (2021) When the Japanese stock market meets COVID-19: impact of ownership, China and US exposure, and ESG channels. Int Rev Financ Anal 74:101670. https://doi.org/ 10.1016/j.irfa.2021.101670

Ur Rehman N, Mandic DP (2011) Filter bank property of multivariate empirical mode decomposition. IEEE Trans Signal Process 59(5):2421-2426. https://doi.org/10.1109/TSP.2011.2106779

Vasileiou E, Samitas A, Karagiannaki M, Dandu J (2021) Health risk and the efficient market hypothesis in the time of COVID-19. Int Rev Appl Econ 35(2):210-223. https://doi.org/10.1080/02692171. 2020.1864299

Xu J, Tan X, He G, Liu Y (2019) Disentangling the drivers of carbon prices in China's ETS pilots-An EEMD approach. Technol Forecast Soc Chang 139:1-9. https://doi.org/10.1016/j.techfore.2018.11. 009

Yaya S, Otu A, Labonté R (2020) Globalisation in the time of COVID-19: repositioning Africa to meet the immediate and remote challenges. Glob Health 16(1):1-7. https://doi.org/10.1186/ s12992-020-00581-4

Yu J, Shi X, Guo D, Yang L (2021) Economic policy uncertainty (EPU) and firm carbon emissions: Evidence using a China provincial EPU index. Energy Econ 94:105071. https://doi.org/10.1016/j. eneco.2020.105071

Ye J, Xue M (2021) Influences of sentiment from news articles on EU carbon prices. Energy Econ. https://doi.org/10.1016/j.eneco.2021.105393

Yu L, Li J, Tang L, Wang S (2015) Linear and nonlinear Granger causality investigation between carbon market and crude oil market: a multi-scale approach. Energy Econ 51:300-311. https://doi.org/10. 1016/j.eneco.2015.07.005

Zeng S, Jia J, Su B, Jiang C, Zeng G (2021) The volatility spillover effect of the European Union (EU) carbon financial market. J Clean Prod 282:124394. https://doi.org/10.1016/j.jclepro.2020.124394

Zhang D (2008) Oil shock and economic growth in Japan: a nonlinear approach. Energy Econ 30(5):2374-2390. https://doi.org/10.1016/j.eneco.2008.01.006

Zhang D (2021) Fiscal policy benefits and green recovery of firms: an experimental exploration of Chinese listed firms in Post-COVID-19. Econ Chang Restruct. https://doi.org/10.1007/ s10644-021-09344-6

Zhang L, Li H, Lee WJ, Liao H (2021) COVID-19 and energy: influence mechanisms and research methodologies. Sustain Prod Consump. https://doi.org/10.1016/j.spc.2021.05.010

Zhang Y, Su S, Xu P, Yao D (2017a) Performance evaluation of Noise-Assisted Multivariate Empirical Mode Decomposition and its application to multichannel EMG signals. 2017 39th Annual International Conference of the IEEE Engineering in Medicine and Biology Society (EMBC): 3457-3460. https://doi.org/10.1109/EMBC.2017.8037600

Zhang Y, Xu P, Li P, Duan K, Wen Y, Yang Q, Zhang T, Yao D (2017b) Noise-assisted multivariate empirical mode decomposition for multichannel EMG signals. Biomed Eng Online 16(1):1-17. https://doi.org/10.1186/s12938-017-0397-9

Zhu B, Huang L, Yuan L, Ye S, Wang P (2020) Exploring the risk spillover effects between carbon market and electricity market: a bidimensional empirical mode decomposition based conditional value at risk approach. Int Rev Econ Financ 67:163-175. https://doi.org/10.1016/j.iref.2020.01.003

Zhu B, Wang P, Chevallier J, Wei Y (2015) Carbon price analysis using empirical mode decomposition. Comput Econ 45(2):195-206. https://doi.org/10.1007/s10614-013-9417-4

Zhu B, Ye S, Han D, Wang P, He K, Wei YM, Xie R (2019) A multiscale analysis for carbon price drivers. Energy Econ 78:202-216. https://doi.org/10.1016/j.eneco.2018.11.007 
Zhu B, Zhang L (2020) COVID-19 induces emissions cut and the development of the digital economy. Retrieved from https://www.iaee.org/en/publications/newsletterdl.aspx?id=882. Last accessed October 20, 2021

Publisher's Note Springer Nature remains neutral with regard to jurisdictional claims in published maps and institutional affiliations.

\section{Authors and Affiliations}

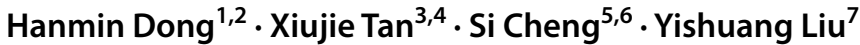

Hanmin Dong

hanmindong@hust.edu.cn

Xiujie Tan

tanxiujie@whu.edu.cn

Si Cheng

chengsi@hbue.edu.cn

1 School of Management, Huazhong University of Science and Technology, Wuhan, China

2 School of Energy and Environment, City University of Hong Kong, Hong Kong, China

3 Institute for International Studies, CICTSMR, Wuhan University, Wuhan, China

4 Climate Change and Energy Economics Study Center, Wuhan University, Wuhan, China

5 School of Low Carbon Economics, Hubei University of Economics, Wuhan, China

6 Center of Hubei Cooperative Innovation for Emissions Trading System, Hubei University of Economics, Wuhan, China

7 School of Economics and Management, Wuhan University, Wuhan, Hubei, China 